\title{
Enterprise capital - Definition, theory and determinants of the structure Marcin Walczak
}

MA, Department of Economics and Finance, Faculty of Law and Social Sciences, Jan Kochanowski University, Kielce, Poland.

Email: marcin.walczak@ujk.edu.pl

\author{
Keywords \\ Capital, Capital Structure, Capital Structure \\ Theories, Enterprise.
}

Article History

Received on $2^{\text {nd }}$ November 2021

Accepted on $15^{\text {th }}$ November 2021

Published on $25^{\text {th }}$ November 2021

Cite this article

Walczak, M. (2021). Enterprise capital

Definition, theory and determinants of the structure. Humanities \& Social Sciences Reviews,

9(6), 29-33. https://doi.org/10.18510/hssr.2021 $\underline{.965}$

\section{Copyright @Author}

Publishing License

This work is licensed under a Creative Commons Attribution-Share Alike 4.0 International License

\section{Abstract}

Purpose of the study: The main goal of the article is to define the company's capital, the concept of which in the literature is insignificant and broad. The subject of the research is also the characteristics of the capital structure and the factors that determine it.

Methodology: The main research method was a critical review of the literature in the field of shaping the capital structure of enterprises, also in the perspective of the evolution of the theory of the optimal capital structure and the factors determining it.

Main findings: The most common definition of capital describes this concept as a source of financing for the activities of an enterprise, and therefore equates it with the balance sheet concept of liabilities. The sources of origin of funds financing business activities forces the managers to search for their optimal structure ensuring the proper relationship between the planned profit and the acceptable level of risk. The literature presents many theories of capital structure and factors shaping it. When shaping the share of equity and borrowed capital in the total of liabilities, one should take into account the business sector of the enterprise, its environment and the risk appetite of the managers.

Application of the study: The presented attempt to define the company's capital is in line with the considerations on this subject so far and aims to standardize this concept in the literature. The cross-section of the theory of capital structure allows for a historical approach to this issue and confirmation of the multidimensionality of the presented issues. The presented factors shaping the capital structure of enterprises specify the areas on which managers should focus when looking for an optimal relationship of equity and foreign capital.

Originality/Novelty of the study: The issue of defining capital and its optimal structure is not new in the literature. However, it requires permanent analysis, which is conditioned by the volatility of macroeconomic and microeconomic conditions. Difficulties in a universal approach to this subject also force detailed research in specific industries and economic conditions. 


\section{Kapital przedsiębiorstwa - Definicja, teorie i determinanty struktury Marcin Walczak}

Mgr, Katedra Ekonomii i Finansów, Wydział Prawa i Nauk Społecznych, Uniwersytet Jana Kochanowskiego w Kielcach, Polska.

E-mail: marcin.walczak@ujk.edu.pl

\section{Słowa kluczowe}

kapitał, struktura kapitału, teorie struktury

kapitału, przedsiębiorstwo.

Historia artykułu

Otrzymano 2 listopada 2021

Przyjęta 15 listopada 2021

Opublikowano 25 listopada 2021

Cite this article

Walczak, M. (2021). Enterprise capital

Definition, theory and determinants of the

structure. Humanities \& Social Sciences

Reviews, 9(6), 29-33. https://doi.org/10.18510

/hssr.2021.965

Copyright @Author

Publishing License

This work is licensed under a Creative Commons Attribution-Share Alike 4.0 Internat ional License

\section{Streszczenie}

Cel badawczy: Głównym celem artykułu jest zdefiniowanie kapitału przedsiębiorstwa, którego pojęcie w literaturze jest nieznaczne i szerokie. Przedmiotem badań jest również charakterystyka struktury kapitału i czynników które ją determinują.

Metodologia: Główną metodą badawczą był krytyczny przegląd literatury z zakresu kształtowania struktury kapitałowej przedsiębiorstw także w perspektywie ewolucji teorii optymalnej struktury kapitału oraz czynników ją determinujących.

Główne wnioski: Najczęstsza definicja kapitału przedstawia to pojęcie jako źródło finansowania działalności jednostki gospodarczej, a zatem utożsamia je z bilansowym pojęciem pasywów. Źródła pochodzenia środków finansujących prowadzenie działalności gospodarczej, wymusza na zarządzających poszukiwanie optymalnej ich struktury, zapewniającej właściwą relację planowanego zysku i akceptowalnego poziomu ryzyka. Literatura przedstawia wiele teorii struktury kapitału oraz czynników ją determinujących. Kształtując udział kapitału własnego i obcego w ogólnej sumie pasywów, należy brać pod uwagę branżę działania przedsiębiorstwa, jego otoczenie i skłonność do podjęcia ryzyka przez zarządzających.

Zastosowanie badania: Zaprezentowana próba zdefiniowania kapitału przedsiębiorstwa wpisuje się w dotychczasowe rozważania na ten temat i dąży do ujednolicenia pojęcia kapitału w literaturze. Przekrój teorii struktury kapitału pozwala na historyczne ujęcie tego zagadnienia i potwierdzenie wielowymiarowości prezentowanej problematyki. Przedstawione czynniki kształtujące strukturę kapitału w przedsiębiorstwach konkretyzują obszary, na których powinni się skupić zarządzający, poszukujący optymalnej relacji kapitału własnego i obcego.

Oryginalność badan: Problematyka zdefiniowania kapitału i jego optymalnej struktury nie jest w literaturze nowa. Wymaga jednak permanentnej analizy, którą warunkuje zmienność uwarunkowań makroekonomicznych i mikroekonomicznych. Trudności w uniwersalnym podejściu to niniejszej tematyki wymuszają również prowadzenie badań szczegółowych w konkretnych branżach i realiach gospodarczych.

\section{Wprowadzenie}

Pojęcie kapitału, pomimo wielu prób jego skonkretyzowania, nadal nie jest jednoznaczne. W literaturze wieloznaczność tego pojęcia ukazywana jest w perspektywie makroekonomicznej i mikroekonomicznej, a więc jako zasób w perspektywie całej gospodarki, jak i konkretnego przedsiębiorstwa.

Konieczność zastosowania w jednostkach gospodarczych środków finansowych pochodzenia wewnętrznego i zewnętrznego, generuje potrzebę opracowania właściwej relacji wielkości funduszy pochodzących z obu źródeł. Stosunek ten (zwany strukturą kapitału) jest przedmiotem wielu rozważań, mających na celu zdefiniowanie optymalnej relacji środków własnych i zobowiązań, mającej na celu maksymalizację zysku oraz wartości jednostki gospodarczej.

Zarządzanie strukturą kapitału, uzależniając od niej efektywność funkcjonowania jednostek gospodarczych, jest istotnym zadaniem kierownictwa przedsiębiorstw. Doświadczenia w tym obszarze działalności, pozwoliły na skonkretyzowanie teorii struktury kapitału, będących pomocą w podejmowaniu konkretnych decyzji. Niniejsze opracowanie ma na celu przedstawienie ogólnej problematyki kapitału i jego struktury w perspektywie istniejących już w literaturze teorii.

\section{Kapitał przedsiębiorstwa - definicja}

Analizując literaturę przedmiotu trudno jest określić jedną, uniwersalną definicję kapitału, choć zdefiniowania tego terminu podejmowało się wielu naukowców z zakresu filozofii, ekonomii i finansów (Kędzior, 2011, s. 46). Wyodrębnienia pojęcia kapitału, odnoszącego się do obszaru gospodarczego, doszukiwać się można w pracach Adama Smitha, który stwierdził, że „kapitał stanowi strumień bądź też krążący fundusz powstały w wyniku procesów 
gospodarczych i jest stworzonym przez pracę czynnikiem wytwórczym" (Pawlonka, 2016, s. 17). Podejście to utwierdza funduszowy charakter kapitału.

Najczęściej w literaturze kapitał utożsamiany jest z pasywami jednostki gospodarczej. Przez pasywa definiuje się wewnętrzne i zewnętrzne źródła finansowania majątku jednostki gospodarczej (kapitał własny i kapitał obcy). Kapitał jako nagromadzone dobro, służy finansowaniu bieżącej działalności jednostki gospodarczej i osiąganiu przez nią założonych celów i utrzymanie przewagi konkurencyjnej (Towarnicka, 2003, s. 20).

Kapitał własny uznawany jest za najbardziej stabilne źródło finansowania działalność gospodarczej. Wraz ze wzrostem zaangażowanego kapitału własnego w ogólnej strukturze pasywów, spada ryzyko upadłości oraz utraty płynności finansowej (Grzywacz, 2012, s. 16). Kapitał własny może pochodzić ze źródeł wewnętrznych (kapitał podstawowy, zysk zatrzymany, zbycie zbędnych składników aktywów trwałych itp.) i zewnętrznych (środki pochodzące z emisji akcji, wzrostu udziałów, dopłaty wspólników itp.) (Duliniec, 2007 s. 31).

Finansowanie działalności jednostki gospodarczej kapitałem obcym, pozwala na zwiększenie poziomu płynności finansowej jednostki, a także pozyskanie dodatkowych środków finansowych, bez poszerzania grona właścicielskiego jednostki. Istotna jest jednak konieczność nieprzekroczenia określanego poziomu udziału kapitału obcego w pasywach. Zbyt duży udział tego składnika grozi konsekwencjami finansowymi, takimi jak utrata płynności a nawet upadłością przedsiębiorstwa (Bielawska, 2001, s 25-40).

\section{Koncepcje struktury kapitału}

Wykorzystywany w bieżącej działalności jednostki gospodarczej kapitał własny, zazwyczaj jest niewystarczający, dlatego zarządzający sięgają po kapitał obcy. Stosunek środków własnych do zobowiązań zdefiniować można jako strukturę kapitału. Właściwe zarządzanie strukturą kapitału prowadzić może do zwiększania wartości przedsiębiorstwa, znajduje to odzwierciedlenie w teoriach struktury kapitału. (Janasz, 2011, s. 105). W literaturze spotkać można wiele nurtów, które odnoszą się do struktury kapitału. Teorie te nawiązuję między innymi do teorii asymetrii informacji i teorii agencji, kwestii podatkowych, kosztów kapitału, kosztów bankructwa i innych czynników wpływających na decyzje finansowe (Barburski, 2018, s 23). Warto przedstawić w tym miejscu najbardziej rozpowszechnione ujęcia modelowe struktury kapitału (Błach, 2009, s. 103):

- Teoria Modiglianiego i Millera - model bez podatków, zakłada, że w świecie doskonałym struktura kapitału nie ma wpływu na wartość rynkową przedsiębiorstwa, ani na średni ważony koszt kapitału (Ociesa, 2021, s. 26);

- Teoria Modiglianiego i Millera - model z podatkami, zakładający, iż tarcza podatkowa wynikająca z zastosowania kapitału obcego powoduje obniżenie kosztu kapitału przedsiębiorstwa, a dzięki temu wzrost wartości rynkowej;

- Model Millera, w którym część korzyści wynikających z zastosowania długu może być utracona w związku z wyższym opodatkowaniem dochodów inwestorów z tytułu posiadania papierów dłużnych, w porównaniu ze stopą opodatkowania dochodów z tytułu posiadania akcji;

- Statyczna teoria substytucji, zakładająca istnienie optymalnej struktury kapitału maksymalizującej wartość rynkową przedsiębiorstwa. Zastępowanie kapitału własnego zobowiązaniami jest opłacalne do momentu przewyższenia kosztów trudności finansowych, czyli kosztów bankructwa przez korzyści podatkowe;

- Teoria substytucji uwzględniająca koszty agencji, zakładająca istnienie optymalnej struktury kapitału maksymalizującej wartość rynkową przedsiębiorstwa. Zastępowanie kapitału własnego długiem jest opłacalne, dopóki korzyści płynące z zastosowania długu (tarcza podatkowa, ograniczenie kosztów agencji) przewyższają zagrożenia wynikające z wysokiego poziomu zadłużenia (koszty bankructwa, koszty agencyjne długu).

Dotychczasowe badania nie podają jednak jednej, uniwersalnej struktury kapitału, która mogłaby być wykorzystywana przez wszystkie przedsiębiorstwa. Decyzje finansowe determinowane są zróżnicowanymi czynnikami, które są indywidualne dla każdej jednostki. Dążenie do osiągnięcia optymalnej struktury kapitału jest więc procesem skomplikowanym i wieloobszarowym.

\section{Czynniki determinujące strukturę kapitału przedsiębiorstw}

Jednym z głównych celów funkcjonowania współczesnych przedsiębiorstw jest maksymalizacja ich wartości oraz zysku. Czynnikiem determinującym osiągnięcie zakładanego celu jest właściwy dobór kapitałów własnych i obcych, uwzględniający w wyborze relację między tymi dwoma wielkościami (Błach, 2009, s. 91).

Czynniki determinujące strukturę kapitału przedsiębiorstwa są klasyfikowane w literaturze według wielu kryteriów. Jako przykład, można wyodrębnić czynniki zewnętrzne (egzogeniczne) i wewnętrzne (endogeniczne). Czynniki zewnętrzne to te, na które podmiot gospodarczy nie ma wpływu, są one związane z makrootoczeniem, czyli dalszym otoczeniem przedsiębiorstwa. Jako przykłady można podać wymienić inflację, sytuację na rynku kapitałowym, system podatkowy, politykę pieniężną i monetarną, branżę działania jednostki. Czynniki wewnętrzne mogą być kształtowane przez przedsiębiorstwo, są związane z otoczeniem bliższym (mikrootoczeniem). Zaliczyć do nich należy: wielkość jednostki, jej rentowność, rodzaj działalności, tarczę podatkową, jakość zarządzania, formę działalności, kapitałodawców (Hajduk, 2018, s. 101). 
Przedsiębiorstwa, realizując proces wyboru konkretnych źródeł finansowania działalności kierują się następującymi kryteriami (Błach, 2009, s. 91-92):

- dostępem do źródeł finansowania, który wynika z sytuacji na rynku finansowym oraz innymi czynnikami pochodzącymi z otoczenia zewnętrznego w perspektywie makroekonomicznej (polityka pieniężna i monetarna, bieżąca koniunktura na rynku instrumentów finansowych, popyt i podaż kapitałowy, obowiązki informacyjne),

- kosztem kapitału, który odpowiada stopie zwrotu z inwestycji wymaganej przez inwestorów przy konkretnym poziomie ryzyka; istotny jest tutaj również koszt pozyskania kapitału z konkretnego źródła związany na przykład z emisją papierów wartościowych, czy prowizjami bankowymi,

- elastycznością, która przejawia się możliwościami pozyskania kapitału na opłacalnych warunkach, które uwzględniają aktualną i prognozowaną sytuację jednostki,

- efektem dźwigni finansowej, który wynika z rodzaju źródła finansowania, stopy oprocentowania kapitału obcego oraz wielkością wygenerowanego zysku operacyjnego, który może być wykorzystany na obsługę kosztów związanych z zadłużeniem,

- ryzykiem operacyjnym, nieodłącznym elementem prowadzenia działalności gospodarczej; czynnik ten powinien mieć również odzwierciedlenie w prognozach dotyczących przyszłej sytuacji finansowej jednostki,

- rozwiązaniami podatkowymi oraz możliwością zaliczenia odsetek od kapitału obcego do kosztów uzyskania przychodu, co obniża podstawę opodatkowania,

- postawą decydentów wobec ryzyka (skłonność, neutralność, awersja), co istotne jest głownie w przypadku wyboru źródeł kapitału obcego,

- aktualną i docelową strukturą własności jednostki (wybór kapitału obcego pozwala na zachowanie niezmienionej struktury własnościowej).

Finansowanie działalności kapitałem własnym przynosi korzyści, ale również straty. Wysoki udział kapitału własnego w strukturze kapitału podnosi znacznie poziom bezpieczeństwa inwestycyjnego, jednak kapitał ten jest kosztowny. Im wyższy udział kapitału własnego, tym z reguły rentowność jest niższa w porównaniu z jednostkami finansującymi działalność korzystając głównie z kapitału obcego (Gostkowska-Drzewicka, 2017, s 25). Każde przedsiębiorstwo realizuje indywidualną politykę kształtowania struktury kapitałowej uzależnioną od warunków funkcjonowania, przedmiotu działalności i polityki finansowej kierownictwa jednostki. Powyższe czynniki należy traktować tylko poglądowo.

\section{Podsumowanie}

Próby zdefiniowania kapitału i jego optymalnej struktury nie jest są tematami nowymi, ale wciąż wymagającymi zgłębiania i kolejnych analiz. Wielość czynników wewnętrznych i zewnętrznych znacznie utrudnia określenie wpływu struktury kapitałowej na wartość i efektywność jednostki gospodarczej. Sprawia to, że możliwość określenia jednej, uniwersalnej relacji środków własnych i obcych jest niejasna.

Opracowanie jednej i uniwersalnej struktury kapitału gwarantującej maksymalizację efektywności staje się bardziej możliwe dla jednostki gospodarczej działającej w konkretnej branży i otoczeniu gospodarczym. Należy jednak stwierdzić, że nawet w takim przypadku optymalizacja struktury kapitału nie może mieć charakteru stałego, ale istnieje konieczność dostosowywania jej do zmieniających się warunków otoczenia, aby zapewnić odpowiednią równowagę między szacowanym przyszłym zyskiem a poziomem akceptowalnego poziomu ryzyka.

\section{Bibliografia}

1. Barburski, J. (2018). Struktura finansowania a wielkość przedsiębiorstw sektora produkcyjnego $w$ Polsce $w$ latach 2011-2016, w: Finanse, Rynki Finansowe, Ubezpieczenia, $\operatorname{nr}$ 2/2018 (92), ss. 23-35. https://doi.org/10.18276/frfu.2018.92-02

2. Bielawska, A. (2001). Podstawy finansów przedsiębiorstwa. Szczecin: Wydawnictwo Zachodniopomorskiej Szkoły Biznesu.

3. Błach, J. (2009). Ewolucja teorii struktury kapitału, w: Finanse: czasopismo Komitetu Nauk o Finansach PAN, nr 1 (1), ss. 87-106.

4. Duliniec, A. (2007). Finansowanie przedsiębiorstwa, Warszawa: Oficyna Wydawnicza SGH.

5. Gostkowska-Drzewicka, M. (2017). Kapitały własne a struktura aktywów przedsiębiorstw deweloperskich, w: Finanse, Rynki Finansowe, Ubezpieczenia, nr 1/2017 (85), ss. 23-34. https://doi.org/10.18276/frfu.2017.1.85-02

6. Grzywacz, J. (2012). Kapitat w przedsiębiorstwie i jego struktura, Warszawa: Oficyna Wydawnicza SGH.

7. Hajduk, A. (2018). Czynniki ksztattujace strukture kapitalu w świetle dotychczasowych badań empirycznych na polskim rynku, w: Prace Naukowe Uniwersytetu Ekonomicznego we Wrocławiu, nr 533, ss. 100-109. https://doi.org/10.15611/pn.2018.533.10

8. Janasz, K. (2011). Determinanty struktury kapitału w przedsiębiorstwie w: Zeszyty Naukowe Uniwersytetu Szczecińskiego. Studia i Prace Wydziału Nauk Ekonomicznych i Zarządzania, nr 21, ss. 103-116. 
9. Kędzior M., (2011). Międzynarodowa struktura kapitału przedsiębiorstw. Ujęcie rachunkowości i finansów, Warszawa: Wydawnictwo C. H. Beck.

10. Ociesa, K. (2021). Determinants of the capital structure of Polish industrial enterprises, w: Zeszyty Naukowe Małopolskiej Szkoły Ekonomicznej w Tarnowie, nr 50 (2), ss. 25-36.

https://doi.org/10.25944/znmwse.2021.02.2536

11. Pawlonka T. (2016). Zastosowanie teorii struktury kapitału dla przedsiębiorstw branży mięsnej w Polsce, Wrocław: Rozprawa doktorska.

12. Towarnicka, H. (2003). Strategia inwestycyjna przedsiębiorstwa, Wrocław: Wydawnictwo Akademii Ekonomicznej we Wrocławiu. 